\title{
GRZEGORZ SZPILA
}

Uniwersytet Jagielloński, Kraków

ORCID: 0000000349606065

\section{Przysłowia w polskim flowklorze}

\section{Wprowadzenie}

Kultura hip-hopu od swoich początków w latach 70. XX wieku znajduje swój wyraz w środkach werbalnych i niewerbalnych, np. w rapie, graffiti, djingu, breakdance, miksowaniu, improwizacji itd. (Sawicki, 2003), i opisywana jest jako zjawisko wielowymiarowe, wielopłaszczyznowe (Szulc, 2014, s. 314, 316). Rap stanowi być może najpopularniejszą i najbardziej skomercjalizowaną formę ekspresji w kulturze hip-hopu i jest, najczęściej pod nazwą muzyki hiphopowej, powszechnym wykładnikiem stylu tej subkultury młodzieżowej ${ }^{1}$, ale sam w sobie jest gatunkiem bardzo zróżnicowanym (Szulc, 2014, s. 315). W latach 90. ubiegłego wieku Shusterman (1998, s. 259) nazwał rap „,najszybciej rozwijającym się gatunkiem muzyki popularnej”. Hip-hop określa się jako gatunek najsprawniej rozprzestrzeniający symbole kulturowe dzięki swojemu migracyjnemu potencjałowi (Malone, Martinez, 2010, s. 532). Zrodzony ponad 40 lat temu w afroamerykańskiej kulturze Nowego Jorku (Bennet, 1999, s. 2), już w latach 80. ubiegłego wieku wydostał się nie tylko poza granice tego miasta, nie tylko poza granice subkultur kolorowych mieszkańców USA, ale w swoim globalnym podboju rozprzestrzenił się także na inne kontynenty, kultury, subkultury, języki i jego odmiany. Rap nazywany jest więc "globalnym fenomenem” (Pennycook, 2003, s. 513) i równocześnie „lokalnym globalizatorem” (Malone, Martinez, 2010 s. 532); terminy te podkreślają globalną manifestację tego muzyczno-kulturowego zjawiska, ale także wskazują na jego potencjał adaptacyjny w obszarach oddalonych pod wieloma względami od jego korzeni. Proces aklimatyzowania się hip-hopu w różnych strefach geograficznych i społecznościach kulturowo-językowych określa się mianem „ulokalnienia”, „indygenizacji”,

\footnotetext{
${ }^{1}$ Rap może być także używany w odniesieniu do śpiewanego tekstu (Berns, Schlobinski, 2003, s. 199).
} 
„reterytorializacji” lub „przywłaszczenia” kulturowego (Androutsopoulos, Schulz, 2003, s. 463; Majewski, 2015, s. 65), co w rodzimych odmianach wyraźnie manifestuje się m.in. w użyciu macierzystego języka i poruszaniu lokalnej tematyki (Pennycook, 2007, s. 106).

Historia badań nad hip-hopem wskazuje zarówno na jego początki, jak i na proces lokalizacji obcego elementu w rodzimych kulturach. Analizy kultury hip-hopu (w tym muzyki) rozpoczęły się na dobre na początku ostatniej dekady XX wieku (Malone, Martinez, 2010, s. 533) wraz z powstaniem pierwszych istotnych wieloperspektywicznych studiów. Naturalną konsekwencją procesów glokalizacyjnych masowej kultury było pojawienie się badań nad cechami hip-hopu zarówno tymi uniwersalnymi, jak i specyficznymi dla danej kultury i języka. W tym nurcie mieszczą się także polskie analizy. Pomimo dużego zainteresowania omawianym tu zjawiskiem i oczywistych postulatów, by zajmować się nim w naukowy sposób (Williams, 2015, s. 2), język hip-hopu pozostaje wciąż terenem niewystarczająco zbadanym, zarówno w kontekście rapu amerykańskiego, jak i w kontekście globalnym tego zdelokalizowanego zjawiska muzycznego (Pennycook, 2007, s. 106; por. Mitchell, 1995, 2010).

Wprawdzie muzyka hip-hopu istnieje od czterech dekad (w Europie aklimatyzowała się w latach 80. ubiegłego wieku, w Polsce pod koniec tej dekady), stając się najintensywniej rozwijającą się wariancją kulturową (Wójtowicz, 2014, s. 183; zob. Pasternak-Mazur, 2009), jednak badania językoznawcze i kulturoznawcze pochylające się nad polskim rapem mają o wiele krótszą historię. Sawicki (2003) i Żmuda (2014) zauważają, że badania nad polskim rapem nie są nazbyt liczne, a Wójtowicz (2014) wymienia tego kilka przyczyn, sprowadzając je do uprzedzeń badaczy względem przedmiotu ewentualnych analiz (szerzej na ten temat Wójtowicz, 2011; por. Shusterman, 1998), którzy hip-hop i rap uważali za „patologiczną formę kultury popularnej” (Majewski, 2015, s. 66). Zasadnicze studia językoznawcze, jak i te o nastawieniu socjologicznym, kulturowym, muzycznym pojawiają się dopiero na początku obecnego millennium ${ }^{2}$. Badacze hip-hopu wciąż formułują postulaty badawcze, mające wyznaczyć metodologię badań kultury hiphopowej, w tym metodologię językową (por. np. poetycko-estetyczno-ideową perspektywę Wójtowicza).

\section{Teksty utworów hiphopowych}

Badany tu materiał będę nazywał utworami hiphopowymi/rapowymi w znaczeniu „rymowanego tekstu” śpiewanego/rapowanego/recytowanego, jak definiuje utwory hip-hopu Chang (2006, s. 545), czyli innymi słowy, analizie poddany zostanie ,język piosenek gatunku muzycznego hip-hop lub rap" (O’Hanlon, 2006, s. 194). Teksty utożsamiane są w niniejszej pracy ze słowami piosenek hip-hopu, które stanowią językowe źródło dla analizy paremicznej podjętej w tym artykule. Stanowią one przedmiot badań, które z jednej strony pomagają dotrzeć do filozofii kultury hiphopowej (do

${ }^{2} \mathrm{O}$ historii hip-hopu i jego manifestacjach w perspektywie globalnej i polskiej zobacz Sawicki (2003). 
charakterystyki jej wartości, por. Kozłowska, 2012, s. 121; Wójciuk, 2017, s. 67-68), z drugiej udzielają odpowiedzi na pytania o wyznaczniki językowe i tekstotwórcze tego stylu. Badania tekstów (języka) hip-hopu mają ambicje wyodrębnić język hiphopowców jako stylistyczną odmianę języka ogólnego, odróżnić go od języka innych subkultur i/lub tekstów piosenek innych muzycznych gatunków (pop, disco, reggae itp.). Pytania zadawane w odniesieniu do angielszczyzny piosenek rapu, tj. czy można mówić o języku specyficznym dla tej subkultury, jak go nazwać, scharakteryzować i odgraniczyć od innych wariantów języka ogólnego (angielskiego w różnych jego odmianach), formułowane przez badaczy (np. Cutler, 2007, s. 520), stawiane są także w kontekście polskiej muzyki hiphopowej. W niniejszym artykule nie ustosunkowuję się do statusu rapu jako gatunku literackiego (por. Chorąży, 2017, s. 131), jak również nie wypowiadam się w kwestii autentyczności/nieautentyczności tekstów poszczególnych wykonawców oraz nie dzielę rapu na „inteligentny” i „nieinteligentny” (por. Kozłowska, 2012).

Teksty hiphopowe charakteryzuje duże zróżnicowanie ideowe, tak jak całą subkulturę hip-hopu (Androutsopoulos, 2010, s. 22; por. Kozłowska, 2012, s. 121). Polskie piosenki hiphopowe, pokazujące specyficzny świat raperów oraz niosące ze sobą interpretacje otaczającej ich rzeczywistości niehiphopowej, odsłaniają całą paletę problemów: od brutalnych realiów codziennego życia środowiska subkultury do klimatów zabawy i cieszenia się życiem (Więsak, 2006, s. 314 i nast.; Miszczyński, 2013). Podkreśla się buntowniczy charakter tekstów hiphopowych, nazywając je nawet protest songami (Więsak, 2006, s. 314; por. Żmuda, 2014). Z jednej strony twierdzi się, że teksty raperów są pełne pesymizmu, pochwał dla narkotyków, przestępczych zachowań (Bernasiewicz, 2009, s. 188; Kozłowska, 2012, s. 127; Szulc, 2014, s. 317-318), z drugiej podkreśla się ich moralizatorski charakter oraz wyrażane w nich zaangażowanie społeczne (Bernasiewicz, 2009, s. 188, 190) w zależności od podejmowanej w nich tematyki: polityka, policja, ekonomia, społeczeństwo, przyjaciele, rodzina, religia, ojczyzna, patriotyzm, do których raperzy ustosunkowują się na różne sposoby (por. Wójciuk, 2017). Teksty piosenek nie stawiają sobie za cel wyłącznie deskrypcji realiów życia, ale pełnią także funkcję budującą - mogą „na swój sposób pouczać, dodawać otuchy [...] informować, jak żyć" (Kajak, 2006, s. 332).

W odniesieniu do polskiego rapu podkreśla się różnorodność środków wykorzystywanych do budowania wypowiedzi artystycznej. Piosenki z jednej strony zawierają więc elementy polszczyzny potocznej, języka różnych subkultur, języka młodzieży, grypsery więziennej, ale równocześnie czerpią z języka literackiego (Moch, 2002, s. 188). Język tekstów rapowych obfituje w neokreacje leksykalne, neosemantyzmy, korzysta obficie z zapożyczeń z języka angielskiego, używa języka metaforycznego i ekspresywnego (tamże). Użyte środki wyrazu - nieuszminkowany język hiphopowców - mają za cel odzwierciedlać opisywaną rzeczywistość (Kajak, 2006, s. 332) oraz wyrażać do niej negatywny lub pozytywny stosunek, ale również sprawiają, że w stosunku do języka hip-hopu stosuje się epitety „wulgarny”, ,chuligański”, „brutalny”, ,arogancki” (Kajak, 2006, s. 129; Kozłowska, 2012, s. 127), co przyczynia się do kreowania negatywnego nastawienia do kultury hip-hopu i rapu w szczególności (Kozłowska, 2012, s. 125). 
Hiphopowcy bez wątpienia pozwalają spojrzeć i na język, i na otaczający nas świat w „odświeżający” sposób (Bradley, 2011, s. 36) za pomocą „,skutecznie silnego języka” (Warren, Evitt, 2010, s. 142).

\section{Przysłowia w tekstach hiphopowych}

Przysłowia ${ }^{3} \mathrm{w}$ tekstach piosenek nie przyciągnęły tyle uwagi badaczy, co obecność paremii chociażby w prasie, sloganach reklamowych, literaturze, chociaż, jak pisze Mieder (2004, s. 224), przysłowia odgrywają ważną rolę także w tworzeniu tekstów utworów muzycznych. Badanie wyzyskania paremii w tekstach piosenek jest jedną z możliwych perspektyw patrzenia na relacje paremii i muzyki. Innym aspektem krzyżowania się tych kategorii jest obecność muzyki w przysłowiach (aspekty rytmiczne, leksykalne, kulturowe i inne), tematyka muzyczna w paremiach lub muzyczne domeny źródłowe prowerbialnych obrazów. W mojej analizie patrzę na proverbia z pierwszej pespektywy, tj. pragnę zastanowić się nad miejscem przysłów w tekstach muzyki rap, za przykład biorąc twórczość polskich grup hiphopowych. Artykuł ten sytuuje się więc w nurcie badań językowo-kulturowych muzyki rap, ma na celu analizę stosunku do paremii wyrażanego przez hiphopowców w ich tekstach, zbadanie, w jaki sposób polscy raperzy wyzyskują paremie w przekazywaniu treści w swoich tekstach, zarówno na płaszczyźnie ich formy, jak i - co ważniejsze - ich treści.

Jako że hip-hop stał się zjawiskiem globalnym, można go badać pod względem cech uniwersalnych łączących jego aktualizacje w różnych kontekstach, równocześnie nieuniknione jest wyodrębnienie w tekstach rapowych elementów lokalnych. Przysłowia są zarówno częścią warstwy uniwersalnej, jak i eksponentem cech lokalnych. Dzieje się tak dlatego, że przysłowia są z jednej strony uniwersalnym typem wypowiedzenia, z drugiej wyrażają częstokroć właściwe danej społeczności sposoby rozumienia, opisywania i regulowania świata. Istnieją naturalnie także paremiczne internacjonalizmy oraz zapożyczenia (chociażby angloamerykańskie, występujące także w analizowanych w tym artykule tekstach rapowych, o czym poniżej). Wyzyskiwanie przez raperów jednych i drugich, świadomie lub nieświadomie, świadczy o atrakcyjności w przekazie hiphopowym takiej paremicznej formy wyrazu, pozwala ona bowiem na odniesienia do treści mniej lub bardziej uniwersalnych oraz do samego paremicznego dyskursu jako formy komunikacji.

W niniejszym opracowaniu traktuję przysłowia przede wszystkim jako elementy języka wspólnotowego, miniteksty, które kryją za sobą wielorakość znaczeń i funkcji. Tworzą one powszechny paremioleksykon, każdemu znany w jakimś wycinku aktywnie lub pasywnie, którego elementy jednakowoż można odrzucić, nie używając ich w ogóle albo wyzyskiwać je na różne sposoby. Są więc traktowane przede wszystkim jako elementy znajdujące się poza kodem hiphopowym (por. Pate, 2010, s. 52), więc interpretacja ich użycia w tekstach hiphopowych przebiega w kierunku dośrodkowym, czyli od form i treści oraz potencjalnej polifunkcji do kontekstów hiphopowych.

${ }^{3}$ O definicji przysłowia i jego miejscu wśród innych jednostek frazeologicznych zob. Szpila, 2003. 
Nie opisuję więc paremii jako elementów języka hiphopowego per se, ale jedynie jako jednostki zewnętrzne w stosunku do języka raperów i intertekstualnie przez nich pożytkowane (por. Picz, 2009, s. 82).

W kontekście zglokalizowanego rapu w Polsce użycie polskich przysłów, jak i języka polskiego, traktuję jako wyraz „lokalnych językowych ideologii” (Pennycook, 2007, s. 92). Tym samym poniższe obserwacje są częścią badań interdyscyplinarnych nad hip-hopem, które powinny charakteryzować badania nad tym zjawiskiem w XXI wieku (tamże, s. 95). Moja analiza stawia sobie za cel wyszczególnienie kilku podstawowych cech paremicznego użycia, ostrożnie podchodzę bowiem do uogólnień, biorąc pod uwagę zróżnicowanie środowiska hiphopowego, jego poglądów, stylów i estetyki. Mam świadomość równocześnie, że tekst piosenek hiphopowych jest spojony w całość z muzyką rapu (por. „rap pod względem estetycznym jest czymś więcej niż tekst”, Shusterman, 1998, s. 285), często wraz z clipem video; jednakowoż utwory hiphopowe będę traktował jako autonomiczne, niezależne od muzyki, od towarzyszących im teledysków, jako teksty każdorazowo zakończone, tym samym nie poddaję analizie innych elementów towarzyszącym utworom hip-hopu (Kajak, 2006, s. 326). Zdaję sobie sprawę również $\mathrm{z}$ tego, że w tekstach tych występują wielokrotnie cechy intertekstualne na wielu płaszczyznach - przecinają się bowiem z utworami tego samego i innych gatunków na wielorakie sposoby. Nie da się uciec także od oczywistej obserwacji, że językowy kształt badanych utworów uzależniony jest od innych cech muzyki rap, co dostrzegam także w operowaniu samą strukturą przysłowia. Niemniej traktuję teksty piosenek hip-hopu, tak jak to czyni Shusterman (1998), mając na uwadze tylko jeden element treści, czyli przysłowia, wierząc, że pominięcie innych aspektów i wątków nie zdeformuje spojrzenia na twórczość polskich raperów.

\section{Przyslowia w polskim hip-hopie - uwagi wstępne}

Przysłowia jako kategoria i jako indywidualne jednostki nie są rzecz jasna wytworem kultury hip-hopu. Nie są także - według moich obserwacji - cechą charakterystyczną języka tekstów hip-hopu ani cechą uwypuklaną przez tekściarzy hiphopowych jak inne jednostki języka polskiego ogólnego oraz językowe twory identyfikowane z językiem hip-hopu. Są natomiast jedną z grup wyrażeń i tekstów (Moch, 2008, s. 50), które wchodzą do piosenek hiphopowych i jak inne zajmują w nich określone miejsce oraz pełnią kontekstualne funkcje. Obecność przysłów w tekstowych manifestach filozofii hiphopowej nie może dziwić chociażby z dwóch ważnych powodów. Po pierwsze, paremie stanowią jedno z niebywale różnorodnych źródeł wzorców językowo-kulturowych, z których czerpie rap. Paremie wraz z innymi frazemami (idiomami, sloganami, powiedzeniami, hasłami, aforyzmami, sentencjami itp.) z chęcią wplatane są w tkankę utworu hiphopowego. Jako wyrażenia figuratywne niejednokrotnie wpisują się w metaforyczny charakter tekstów raperów (por. „porównania metafory będziemy dawać” w Porównania Starego Miasta, „śmigam po przenośniach i po metaforach” we Wracam rapera Te-Tris i wiele innych). Po drugie z kolei, przysłowia stanowią ważny 
punkt odniesienia w prezentowaniu osobistej wizji świata hiphopowców, która częstokroć konstytuuje się w kontekście filozofii regulującej, w kontekście uogólniających obserwacji i sądów.

Przysłowia w pierwszej kolejności należy rozpatrzyć jako to, czym często się je określa, czyli mądrości, której powszechna akceptowalność odzwierciedla się w ich tradycyjnym trwaniu w świadomości i w języku danej społeczności. Jako zbiór przysłów paremioleksykon służy swym materiałem do gotowych wypowiedzi na różne tematy. Mówiąc bardzo ogólnie, przysłowia służą radzeniu sobie z wszelakimi sytuacjami życiowymi w celu znormalizowania zachowań według określonych zasad, które wydają się obowiązywać niezależnie od indywidualnych „odchyleń”, wbrew zindywidualizowanym rozwiązaniom. Wyznaczają więc model jak gdyby narzucany z góry, przez większość, przez wszystkich, i wydają się prowadzić do uniformizacji. Taki właśnie zbiór zasad stanowi punkt odniesienia dla autorów hiphopowych jako kategoria, ale także zbiór poszczególnych egzemplifikacji. Odwoływanie się do proverbiów wywołuje pytania o to, z czego, jeśli w ogóle, raperzy czerpią mądrość. Używanie przysłów nie oznacza zawsze przejmowania z nich zdroworozsądkowej filozofii, jak pokażą poniższe analizy, a jedynie wyzyskiwanie zasobów językowo-kulturowych do budowania indywidualnych wypowiedzi.

Klimat antyprzysłowiowy jest namacalny w tekstach hiphopowych. Dążenie do samodzielności w myśleniu, a także pozytywne wartościowanie własnego, indywidualnego, niestadnego myślenia prowadzi do pielęgnowania negatywnego stosunku do przysłów (inne użycie przysłów przez raperów w żadnym wypadku nie stoi w sprzeczności z takim nastawieniem do mądrości paremicznych). Przysłowia są odrzucane, nie stanowią bowiem prostego przedłużenia i podsumowania doświadczenia (,,i z doświadczeń wyciągam mądrość, nie z przysłów" w Nienawidzę zbyt często rapera Flinta, bo „Doświadczenie - mądrości krynica” w utworze Gloria Victis autorstwa Piha). Nie są akceptowane, gdyż nie przystają do rzeczywistości opisywanej przez hiphopowców (,,znasz to z wiedzy mistrzów i magii przysłów, powtarzając tępo słowa niewarte nic dziś już” w Echo miasta O.S.T.R.-a). Nie są używane, bo nie trzeba się do nich uciekać, chcąc stworzyć wartościowy przekaz (,,by nadal mówić mądrze, nie używamy przysłów” według Hi-Fi Banda w Każdy dzień). Przysłowia są odrzucane także jako mądrości indywidualne, mądrości, które bledną w zderzeniu z rzeczywistością prezentowaną w piosenkach hiphopowych. Jest to wyraźnie widoczne w tekście Przysłowia rapera Penxa oraz w utworze pod tym samym tytułem zespołu Fenomen, w których ocenie poddawanych jest wiele przysłów:

1. „Przyjaciół poznaje się w biedzie, teraz jest inaczej ziomy ${ }^{4}$

Tak jest prawie wszędzie więcej hajsu więcej masz znajomych

Weź mnie nawet już nie wkurwiaj chyba cię zbesztam idioto

${ }^{4}$ Cytaty pochodzą z różnych źródeł (główne wymieniono niżej), najczęściej nieoficjalnych, „fanowskich", więc zawierają one liczne błędy, część zapisów jest programowo niedbała. Podczas opracowywania artykułu poprawiono ewidentne pomyłki, a w ramach przysługującej twórcom tekstów licentia poetica część zapisów pozostała w wersji, do której dotarł autor. 
Pierdol tych co plotą w stylu przyjaźń cenniejsza niż złoto".

„Przejrzyj, pieniądze nie dają szczęścia

Jesteś trzeźwy? pewny, że jest tak bezdomny odda wszystko żeby gdzieś zamieszkać

I tylko tyle mu brakuje do tak zwanego szczęścia (...)

Kto pod kim dołki kopie znasz też ale ty cztery razy wpadniesz, zanim on się natnie".

Można by powiedzieć bez analizowania otoczenia użytych przysłów, że hiphopowcy nie klasyfikują wyrażeń, które wyzyskują i akceptują explicite jako paremie. Jednakże, z drugiej strony, wiele z wyrażeń jednoznacznie identyfikowanych jest jako przysłowia, o czym świadczy spożytkowanie paremicznych tagów wprowadzających i automatycznie identyfikujących użytą jednostkę.

2. „Nieszczęścia chodzą parami? Tylko w przysłowiach” (Hukos\&Cira, Supet).

3. „Znam takie przysłowie wiesz - śpiesz się powoli” (Elegans, Nareszcie - tak być).

4. „Jak mówi przysłowie - co za dużo to niezdrowo” (LSP, Ile jeszcze?).

5. „I tylko w przysłowiu szewc chodzi boso” (Tede, Moje życie jest tu).

6. „Znasz to przysłowie - winni się thumaczą” (Chada, P.M.T.).

7. „Jak głosi przysłowie, ty pomożesz ja pomogę” (Chłopaki z Szarego Tłumu, Rusz się rusz).

8. „Znasz przysłowie: ostrożnie przyjaciół sobie dobierz” (Fokus, Prewersje).

9. „Więc pierdol paranoje i pamiętaj przysłowie

Im więcej potu na treningu tym mniej krwi na ringu” (DJ Deszczu Strugi, Jedziesz 2).

10. „Stare przysłowie mówi, że przed libacją dobrze coś zjeść” (CeZik i Klejnoty, Wóda to śmierć).

11. „Tropię trupy pełne trupów, trudny zawód, ty tworzysz doły dla dzieciaków, znasz przysłowie he?” (White House, Tau, Łowca).

12. ,Jest starym porzekadłem, że oczy dusz zwierciadłem, co było widać w moich, gdy tak blisko dna upadłem?" (A.J.K.S., 1320).

I właściwie nie ma znaczenia, czy otagowane wyrażenia są przysłowiami, czy do nich pretendują, czy są aluzyjnie przywoływane, czy są polskie, czy obce. Powyższe przykłady wskazują na postrzeganie pewnych wyrażeń w kategoriach przysłowiowych oraz nadawanie wyrażeniom tradycyjnie nieparemicznym takiego charakteru. Pokazuje to, wydaje mi się, istnienie kategorii przysłów w mentalnym leksykonie paremicznym tekściarzy, a także obecność w nim konkretnych formuł paremicznych.

Można powiedzieć, że przytoczeni tekściarze odrzucają przysłowia jako wyrażenia kojarzone $\mathrm{z}$ prawdami niepodawanymi w wątpliwość, akceptowanymi w całej ich rozciągłości (por. „przyjęli świat jak głupcy bez namysłu mądrość biorąc z przysłów”, jak śpiewa Eldo w Opakowani w folie), natomiast proverbia weryfikowane w ramach własnego doświadczenia mogą być włączone w repertuar „ulicznej” mądrości. Wydaje się z drugiej strony, że raperzy z chęcią wykorzystują poszczególne przysłowia, o ile nie stoją one w sprzeczności z ich postawą, w celu prezentowania własnej filozofii życia. Tak więc w tekstach hiphopowych odnajdujemy niemało przykładów akceptowania przysłów, co więcej, nawet afirmacji ich prawd, na przykład: 
13. „teraz już wiem milczenie jest jak złoto dlaczego każda dupa zawierza wszystkim plotom” (Chada, Jarecki, Pih, Sitek, DonGuralesko, P.M.T.).

14. „niesiemy prawdę we własnym tempie, co nagle to po diable” (Chada, Niesiemy prawdę).

15. „,nie będziemy tu rozmawiać o gustach, jakaś panna całuje mnie w usta” (B.R.O, Gorzka Czekolada).

16. „wokół mnie niby sami przyjaciele, tych prawdziwych poznam tylko w biedzie” (Jajo\&P.A.G, Fiołas, Wiatr W Oczy...).

Te przykłady i wiele innych nie udowadniają oczywiście, że przywoływane przysłowia zawsze tak są traktowane. W zależności od „doświadczenia” jedną i tę samą paremię może spotkać w różnych utworach całkiem inny los. Nie trzeba chyba przypominać, że ujawnia to doskonale polisytuacyjność i polifunkcyjność proverbiów, których znaczenie i rolę doprecyzować może jedynie kontekst, a kontekst w przypadku większości utworów hip-hopu to wypadkowa wielu czynników.

\section{Paremiczna analiza hip-hopu}

Poniższa analiza podzielona jest na dwie główne części: formalną i semantyczną. Kieruję się tutaj kryterium przejrzystości; dodatkowo ten podział pozwala umiejscowić raperskie działanie na paremiach w szerszym kontekście, czyli wśród zachowań językowych postrzeganych z czysto formalnego punktu widzenia, jak i z perspektywy sposobów aktualizacji formalnych samych paremii. Tak samo uczynię w drugiej części, bowiem zwrócę uwagę na miejsce proverbiów w filozofii polskiego hip-hopu, ale także umiejscowię działanie paremiczne w szerszym kontekście paremiosfery języka polskiego.

Badany materiał tworzą 104 utwory zawierające co najmniej jedno przysłowie. Utwory te wybrałem z obszernej bazy piosenek hiphopowych dostępnych na polskich stronach internetowych. Najważniejsza strona, z której korzystałem przy zbieraniu materiału, to www.polskirap.net. W ustalaniu właściwych form paremii posługiwałem się stronami z tekstami piosenek (www.polskirap.net, www.tekstyhh.pl, www.tekstyhh.blox.pl). $\mathrm{W}$ wyselekcjonowanych utworach znalazłem 73 przysłowia, które były użyte w sumie 121 razy. Poniższa lista zawiera struktury zaklasyfikowane jako paremie na potrzeby niniejszego opracowania.

- Biednemu zawsze wiatr w oczy.

- Bóg pomaga tym, co sami sobie pomagają.

- Carpe diem.

- Chcieć to móc.

- Co dwie głowy, to nie jedna.

- Co kraj, to obyczaj.

- Co masz zrobić jutro, zrób dziś.

- Co nas nie zabije, to nas wzmocni.

- Co nagle, to po diable. 
- Co się stało, to się nie odstanie.

- Co za dużo, to niezdrowo.

- Czas goi rany.

- Czas to pieniądz.

- Człowiek człowiekowi wilkiem.

- Człowiek uczy się na błędach.

- Czym skorupka za młodu nasiąknie, tym na starość trąci.

- Diabeł tkwi w szczegółach.

- Do odważnych świat należy.

- Do wesela się zagoi.

- Fortuna kołem się toczy.

- Gdzie kucharek sześć, tam nie ma co jeść.

- Gdzie się dwóch bije, tam trzeci korzysta.

- Głową muru nie przebijesz.

- Jak cię widzą, tak cię piszą.

- Jak wejdziesz między wrony, musisz krakać jak i one.

- Jaki ojciec, taki syn.

- Jeden za wszystkich, wszyscy za jednego.

- Każdy jest kowalem swego życia.

- Każdy sobie rzepkę skrobie.

- Kot ma dziewięć żyć.

- Kropla drąży skałę.

- Kto nie ryzykuje, nic nie ma.

- Kto pod kim dołki kopie.

- Kto pyta, nie błądzi.

- Kto sieje wiatr, ten zbiera burzę.

- Kuj żelazo, póki gorące.

- Kwiecień plecień, wciąż przeplata, trochę zimy, trochę lata.

- Mądry Polak po szkodzie.

- Mowa jest srebrem, a milczenie złotem.

- Nadzieja matką głupich.

- Nadzieja umiera ostatnia.

- Nie czyń drugiemu, co tobie niemiłe.

- Nie ma tego złego, co by na dobre nie wyszło.

- Nie oceniaj książki po okładce.

- Nieszczęścia chodzą parami.

- O gustach się nie dyskutuje.

- Oczy są zwierciadłem duszy.

- Ostatni będą pierwszymi.

- Pan Bóg nierychliwy, ale sprawiedliwy.

- Piekło jest dobrymi chęciami wybrukowane.

- Pieniądze szczęścia nie dają.

- Poznasz po słowach, nie po czynach. 
- Pozory mylą.

- Pożyjemy, zobaczymy.

- Praktyka czyni mistrza.

- Prawdziwych przyjaciół poznaje się w biedzie.

- Przeciwieństwa się przyciągają.

- Przez żołądek do serca.

- Raz kozie śmierć.

- Ręka rękę myje.

- Sky is the limit.

- Spiesz się powoli.

- Stara miłość nie rdzewieje.

- Sukces ma wielu ojców.

- Szewc bez butów chodzi.

- Ten się śmieje, kto się śmieje ostatni.

- Tonący brzytwy się chwyta.

- Trawa jest bardziej zielona po drugiej stronie płotu.

- Umiesz liczyć, licz na siebie.

- $\quad$ Z małej chmury duży deszcz.

- $\quad$ Z rodziną (dobrze się wychodzi) tylko na zdjęciach.

- Życie zaczyna się po czterdziestce.

- $\quad \dot{Z} y j$ i daj żyć.

Na liczbę wszystkich użytych w analizie przysłów składają się przede wszystkim tradycyjne przysłowia polskie. Niemałą grupę tworzą kalki paremiczne, stworzone na podstawie wzorców przysłów anglosaskich. W analizowanych utworach polskich raperów wynotowałem następujące ślady paremiczne o obcej proweniencji:

17. „Trawa zieleńsza rośnie tylko w miejscach gdzie indziej” (Afro Kolektyw, Gościnne występy).

18. „Wiesz u sąsiada trawa zawsze jest tańsza” (Abradab, Dla każdego jego raj).

19. „Podobno życie zaczyna się po trzydziestce” (DJ Decks, Praż albo giń).

20. „Tak jak wiesz, nie oceniaj książki po okładce” (Młody M, Uzależnienie).

21. „Wielu ludzi szacuje innych po okładce” (Fundacja \#1, Nie znasz mnie).

oraz oryginalne formy, takie jak „Sky is the limit” (Potwierdzone Info, Jestem stąd). Z jednej strony ich obecność można, być może, wytłumaczyć występowaniem paremii angielskojęzycznych w niepolskich utworach hiphopowych (w tym amerykańskich, inspirujących polskich raperów), z drugiej popularnością tych polskich form anglosaskich paremii we współczesnej polszczyźnie (por. Szpila, 2014a, 2014b).

Jest rzeczą wątpliwą, czy można na podstawie częstotliwości występowania konkretnych przysłów wysnuwać wnioski na temat dominujących motywów przekazywanych za pomocą paremii. W moim materiale bowiem nie zaobserwowałem jednoznacznej dominacji konkretnych jednostek paremicznych ani nie udało mi się ustalić, jakiego typu 
przysłowia, z formalnego i semantyczno-pragmatycznego punktu widzenia, są najczęściej używane. Mało pomocne jest także grupowanie przysłów w pola tematyczne, choć taki sposób patrzenia na zebrany materiał może być punktem wyjścia w innej analizie. Bo czy na podstawie obecności Nie oceniaj książki po okładce i Pozory myla z jednej strony oraz Co nagle, to po diable i Spiesz się powoli z drugiej można przypuszczać, że raperzy konsekwentnie koncentrują się na przekazie tych mądrości? Chociaż najczęściej występujące w materiale to Prawdziwych przyjaciót poznaje się w biedzie i Co cię nie zabije, to cię wzmocni (występują sześć razy), nie odważę się postawić tezy, że najważniejsze paremicznie wyrażane tematy muzyki hiphopowej czy nawet treści analizowanych tekstów to lojalność oraz budowanie integralności moralnej, nawet jeśli przypisze im się bardzo ważne hiperfunkcje i metafunkcje w kontekście piosenek, a nawet kultury hip-hopu (por. niżej). Sama obserwacja paremii podanych w formie listy nic nie mówi o zaangażowaniu ich $\mathrm{w}$ ewentualne przesłanie zawierających je utworów - bezkontekstowa statystyka proverbiów może być jedynie pierwszym krokiem (być może nie najważniejszym) w poszukiwaniu odpowiedzi na inne, istotniejsze pytania. Statystyki pokazują jednoznacznie nierzadką obecność paremii w utworach polskich raperów, ich roli nie da się jednak ustalić na podstawie prostego paremiograficznego wyliczenia jednostek.

\section{Analiza formalna}

W analizie strukturalnej paremii występujących w tekstach hip-hopu ograniczę się do uwag na temat budowy syntaktycznej i leksykalnej proverbiów. Niemniej, jako że forma paremii wpływa w dużej mierze na interpretację semantyczną paremicznych loci, w wielu wypadkach wskażę na relacje między aspektem strukturalnym i znaczeniowym wyzyskanych przysłów.

Tekstów hiphopowych nie charakteryzuje jeden sposób użycia przysłów, pojawiające się w utworach formy paremii oscylują formalnie między kształtami kanonicznymi, mniej lub bardziej ustabilizowanymi leksykograficznie, a różnymi rodzajami modyfikacji i transformacji. Analizowane teksty hiphopowe zawierają wiele paremicznych loci z kanonicznymi formami przysłów:

22. „Śpiesz się powoli jeszcze będzie czas” (Zipera feat. Dragon Davy, Toma, Bez ciśnień).

23. „Się dowiedzieli wtedy że mądry Polak po szkodzie. A czas goi rany” (Penx, Przystowia).

24. „Jaki ojciec, taki syn, czyli czyn też?” (Fenomen, Przystowia).

25. „We własnym tempie, co nagle to po diable” (Chada, Hukos, Sitek, Pezet, Pih, DonGuralesko, Jarecki, Niesiemy Prawdę).

26. „Jak mówi przysłowie - co za dużo to niezdrowo” (LSP, Ile jeszcze?).

Ale nawet w przypadku form prototypowych wydaje się, że istnieje relacja między wyborem formy i cechami poetyckimi tekstu, z których najważniejsze to rytm i rym. Rzeczą ciekawą jest, że wszystkie cytowane poniżej przysłowia są krótkie, są strukturami, które łatwiej dopasowują się więc do kształtu formalnego utworów: 
27. „Człowiek, człowieka wykręci, człowiek wilkiem człowiekowi.

Wszystkim pseudo prawilniakom chuj znów wbijam do połowy" (Firma, Niełatwy żywot ulicznego rapera).

28. „Pamiętaj! Nie czyń drugiemu, co tobie niemiłe

Źle życzysz bliźniemu? Obyś złapał kiłę" (DonGuralesko, Pamiętaj).

Kontekst formalny wymusza częstokroć także niewielkie zmiany syntagmatyczne w obrębie paremii:

29. „Prawdziwych przyjaciół w biedzie się poznaje

Ale jeszcze to trochę do myślenia daje" (WBU, Na zawsze).

30. „Nie każdemu się zawsze dobrze wiedzie

I pamiętaj prawdziwych przyjaciół poznaje się w biedzie" (Molesta, Klima).

31. „Co kraj to obyczaj, ale nas w to nie wliczaj” (Te-Tris, Obudź się).

W powyższych przykładach, jak i w przypadku strukturalnej dezintegracji paremicznej, np. „Wokół mnie niby sami przyjaciele, tych prawdziwych poznam tylko w biedzie” (Jajo\&P.A.G/Fiołas, Wiatr W Oczy...) i „Śmiejesz się, zgadnij, kto się będzie śmiał ostatni” (Peja/Slums Attack Co cię boli), nadrzędnym celem wydaje się wplecenie tekstu przysłowiowego do tkanki utworu hiphopowego, mającego określone cechy rymowo-rytmiczne, co nie prowadzi do żadnych przesunięć semantycznych, nadwyżek, zawężenia czy antonimicznych znaczeń.

Cechy konkretnego utworu, ograniczenia narzucone długością wersów, wewnętrznym rytmem, rymami wewnętrznymi i zewnętrznymi mogą także redukować, aczkolwiek nieznacznie, formy przysłów, jak pokazują to poniższe przykłady:

32. „Teraz już wiem, milczenie jest jak złoto” (Chada, P.M.T.).

33. „»Przeciwieństwa przyciągają《 coś w tym jest i te dwa Pe”

Od dziś stanowią jedność, o tym ten kawałek jest" (Peja, $K C$ ).

34. „Jest starym porzekadłem, że oczy duszy zwierciadłem” (A.J.K.S., 1320).

35. „Co kraj - obyczaj, ale tego nie czaję” (Pih, 40\%).

W drugim kierunku idą te paremiczne loci, w których dostrzegamy rozszerzenie przysłowiowej struktury, za czym podąża znaczne wzbogacenie semantyki wypowiedzi paremicznej5:

36. „Ciągle prędzej i prędzej, czas to pieniądz, a pieniądz to sensej” (DonGuralesko, Co to za miejsce).

Najciekawsze według mnie są wymiany leksykalne dokonywane w kanonicznych paremiach. Tutaj właściwie dostrzec możemy próby przeorientowywania zasadniczego

${ }^{5}$ Warto zauważyć, że zacytowane wyżej paremie nie zawsze mają kształt zgodny z formami leksykograficznie skodyfikowanymi (np. „Człowiek wilkiem człowiekowi”, zob. przykład 27), jednakże takie drobne przekształcenia nie wywołują według mnie poważnych zmian w znaczeniu jednostki wyjściowej. 
znaczenia przysłowia. Substytucje wyrazowe mogą mieć jedynie charakter kosmetyczny, przynoszą niewielkie zmiany znaczeniowe lub nie wnoszą niczego nowego do semantyki paremii, jak na przykład: „Człowiek człowiekowi wrogiem” (Onar, Przez wizjer), w którym następuje demetaforyzacja, i „Człowiek jest tylko pionkiem w grze miasto to plansza, wbrew temu, co mówią diabeł tkwi w niuansach" (Kaczor, Szukając siebie), w którym zmiana synonimiczna podyktowana rymem nie modyfikuje znaczenia proverbium Diabeł tkwi w szczegółach lub „Kasa szczęścia nie daje, głupi ten kto za nią goni!” (Karramba, By nie żyć na dnie) czy nawet „co ma się stać to się stanie” z utworu Jedno jest życie (Jeden Osiem L). W innych natomiast dostrzegamy większą wagę zmian leksykalnych, także dzięki sprzężeniu ich z innymi efektami poetyckimi:

\section{7. „Magda ma męża, ale w niedzielę i wtorek}

Pełznie u kochanka do serca przez rozporek" (Pih, Seks w wielkim mieście).

38. „Bierze z lodówki Jacka Daniel'sa i czeka na wejścia

Księga przysłów: przez Jacka do serca" (Rasmentalism, Kupuj polskie rap ptyty).

Te ukontekstowione zmiany mają, według mnie, już charakter antyparemiczny, tak jak przykładowo „Gdzie kucharek sześć tam kurwa cycków dwanaście” (Penx, Przysłowia). Ukazują oczywiście wybór silnie nacechowanego emocjonalnie języka, konkretności obrazowania, wulgaryzację wypowiedzi.

Niektóre paremiczne loci wymagają od słuchacza/czytelnika odniesienia do znanych mu przysłów, utwory hiphopowe przywołują je bowiem w sposób zmodyfikowany. Poniższe przykłady nawiązują do przysłów Kot ma dziewięć żyć (ang. A cat has nine lives), Tonacy brzytwy się chwyta, Kto pod kim dołki kopie, ten sam w nie wpada oraz $Z$ rodzina najlepiej wychodzi się na zdjęciach.

39. „Nie mów nawet mi, ile można na tym zgarnąc Jak chcesz zarobić kwit, proszę bardzo, to jest za mną I ciągnie się do dziś, a nie mamy siedmiu żyć Więc fajnie, że jest zysk, ale nie chcę w pierdlu gnić" (Pezet/Małolat/Małpa, Nagapilem się).

40. „Wciąż wierzę w prawdę, wiesz, wciąż mam swój honor zamiast łapać się brzytwy, wolę utonąć i mieć twarz wśród tych, co z wyciągniętą dłonią proszą o pomoc" (O.S.T.R., Echo miasta).

41. „Bo na końcu swojej tęczy chcieliby pekiel

Kopią dołki, chcą byś wpadł" (Ry23, Wola walki).

42. „Ona to pamięta, znasz to przysłowie - rodzina, lecz na zdjęciach” (KrzyHu/EnWuEs, Pozwól zasnać).

Przysłowia obce i kalki paremiczne mogą także pojawiać się w formach niezmienionych albo ulegać modyfikacji, przykładowo:

43. „Tak jak wiesz, nie oceniaj książki po okładce” (Młody M, Uzależnienie).

44. „Wielu ludzi szacuje innych po okładce” (Fundacja \#1, Nie znasz mnie).

45. „Trawa zieleńsza rośnie tylko w miejscach gdzie indziej” (Afro Kolektyw, Gościnne występy).

46. „Lecz podpowiada mu coś żądza opętańcza, 
Wiesz u sąsiada trawa zawsze jest tańsza" (Abradab, Dla każdego jego raj).

47. „Dzieciaków, które wierzą, że „sky is the limit” (Potwierdzone Info, Jestem stąd).

48. „Jest pewna dewiza, którą znam: Carpe diem” (Paktofonika, Ulotne chwile).

Przekształcenie formy przysłowiowej może stworzyć nowy wariant oryginalnej paremii (Bładzisz, to pytaj jako tytuł utworu Mumina). Paremiczne struktury typu „Jakie życie, taki rap" z utworu Pei Mój rap, moja rzeczywistość nawiązują do binarnej struktury wielu paremii, w tym zauważonej w analizowanym materiale paremii Jaki ojciec, taki syn. Może dochodzić także do deprowerbializacji strukturalnej przysłowia (czyli derywacji) wtedy, kiedy forma zdaniowa przekształcona jest na frazę nominalną lub werbalną:

49. „Głowami przebiliśmy bracie ten jebany mur” (Zeus, Znasz Mnie).

50. „Nie będziemy tu rozmawiać o gustach” (B.R.O, Gorzka Czekolada).

51. „Nauka na błędach, uczy nas jak potem przetrwać” (Polska wersja, Licz na siebie).

Jak wskazano wyżej, w tekstach utworów hiphopowych paremie przyjmują wiele kształtów. Obok form całkowicie kanonicznych pojawiają się różne zmienione formy. Z perspektywy semantycznej paremiczne struktury ulegają przeróbkom, które niekoniecznie służą przekształceniu znaczeń przysłów w antyprzysłowia (rozumianego jak w Mieder, 2004, s. 281). Zauważyć należy, że wiele zmian jest stosowanych bardziej pod wpływem formy rapowanej, reguł narzuconych przez rapowy charakter muzyczno-tekstowego performance niż przez sam zamysł semantyczny czy kontekst aksjologiczny. Niemniej kilka przykładów wskazuje na to, że dokonywane zmiany są elementem nie tyle zabawy z ustabilizowaną formą dla celów ludycznych - powiedzmy - czy dla czysto językowej manipulacji, ile dokonuje się ich ze względu na przesłanie, które przyświeca konkretnemu paremicznemu locus, konkretnemu tekstowi czy nawet message'owi muzyki hiphopowej. Właśnie te ostatnie zmiany są najciekawsze z uwagi na cele przyświecające tej analizie; zostaną one szerzej omówione w następnej części artykułu.

Można oczywiście zastanowić się, do jakiego stopnia naruszanie struktury przysłowia samo w sobie sygnalizuje manifest hip-hopu, manifest językowy wobec narzuconych tradycją i uzusem form. To wyjaśnienie użycia transformacji jeszcze bardziej wydaje się zasadne w obliczu kluczowej dla muzyki hip-hopu autokreacji bazującej także na panowaniu nad językiem i tworzeniu własnego zindywidualizowanego idiolektu artystycznego, odrzucającego formalnosemantyczne wzorce. Myślę, że można postrzegać w ten sposób wszystkie operacje na języku zastanym, w tym formulicznym, w tekstach omawianego gatunku muzycznego.

\section{Analiza semantyczna}

Analogicznie do poprzedniej części analizę semantyczną pragnę rozpocząć od użyć przysłów, które respektują znaczenia prototypowe paremii i które nie negują - ogólnie rzecz ujmując - przekazu paremicznego. Chodzi tu o konteksty paremiczne, w których 
nie dochodzi do formalnego zaburzenia struktury, oraz tzw. konteksty prototypowe, które mogą być wyznaczone dla konkretnego proverbium (por. Szpila, 2005). Takie użycie paremii oznacza potwierdzenie treści, którą niesie struktura, oraz wykorzystanie jej do wyrażenia własnych poglądów. Paremia może z jednej strony wpisywać się w szerzej rozumiany światopogląd hiphopowy lub w światopogląd przypisywany innym. W konsekwencji mamy tu do czynienia z wpisaniem przesłania paremii w treść utworu i utożsamienie się z zawartym w przysłowiu przekazem oraz użycie go w komunikacji ze słuchaczem. Z drugiej strony, użycie proverbium charakteryzuje inną paremiczną wizję, z którą niekoniecznie zgadza się autor utworu hiphopowego, przywołuje ją jednak jako eksponent wyznawanych przez innych poglądów, wobec których pragnie określić swoje własne stanowisko. Poniższe fragmenty ilustrują kanoniczne loci:

\footnotetext{
52. „Głową rusz, uwierz w siebie, skrusz niewoli jarzmo

Pozostaw za sobą niepowodzeń pasmo

Lecz nie dolewaj do ognia oliwy

Wiesz Pan Bóg nie rychliwy

Ale sprawiedliwy

Odnajdź szczęście, aby być szczęśliwym

Dziś jesteś zwierzyną, a jutro myśliwym"

(Molesta Ewenement, Dobrze będzie, dzieciak).

53. „Niełatwe jest życie ulicznego rapera,

Codziennie atmosfera twoje nerwy tutaj wyżera,

Codziennie pruje się do ciebie jakaś ponura cholera!

Codziennie nie docenia cię ktoś, czasem to doskwiera.

Człowiek, człowieka wykręci, człowiek wilkiem człowiekowi”"

(Firma, Niełatwy żywot ulicznego rapera).
}

54. „Pozory mylą tak bardzo jak siemasz,

Twarz pięknych kobiet często szpeci tapeta" (Diox/The Returners, Pozory myla).

55. „Evo, nie rewolucja, to nie cytat z niczego

Tak z niczego, wyjazd na rap drzewo

To te produkcje na lewo, niesiemy prawdę

We własnym tempie, co nagle to po diable" (Chada, Hukos, Sitek, Pezet, Pih, DonGuralesko, Jarecki, Niesiemy prawdę).

\section{6. „Nie każdemu zawsze się dobrze wiedzie}

I pamiętaj prawdziwych przyjaciół poznaje się w biedzie

Teraz wszystkich bliskich chciałem zdrowie wypić

Dobre chłopaki z Klimy możecie zawsze na mnie liczyć" (Molesta, Klima).

Drugi typ egzemplifikują utwory, w których przysłowia są używane jako cytacje: „Mama Ci powie: Jaki ojciec taki syn, Usłyszysz od nieznajomych, że jesteś nikim” (Pih, Nie płacz), lub są przypisywane innym jako wyraziciele ich poglądów: „Dzieciaków, które wierzą, że »sky is the limit«" (Potwierdzone Info, Jestem stąd). Są one wkładane w usta innych uczestników procesów komunikacyjnych, o których wspominają utwory. Zawsze jednak przysłowie pozostaje sposobem wyrażenia pewnego poglądu, bez względu na to, czyje usta je wypowiadają. 
Przysłowia stanowią budulec tekstów hiphopowych na poziomie ich makro- i mikroorganizacji. Innymi słowy: paremia, po pierwsze, może semantycznie organizować całość utworu, co nierzadko sygnalizuje sam jego tytuł. Przykładem ekstremalnym w zebranym materiale są utwory rapera Penxa pt. Przysłowia i grupy Fenomen Przysłowia, w których muzycy rozprawiają się - można by rzec - z tymi formułami. W innych przypadkach tytuł zawiera konkretne przysłowie, stanowiące semantyczną klamrę dla całości. Przykładem takich utworów jest piosenka Spiesz się powoli Grubsona:

57. „Pozwól odnaleźć siebie, do celu zostało niewiele,

Więc spiesz się powoli ziombel, niech serce tobą kieruje,

Niech muzyka w nim płynie, a życie uchyli tajemnicy rąbek, yo..."

Podobnie jest w przypadku utworów Pozwól żyć innym (Jeden strzał), Wiatr W Oczy... (Jajo\&P.A.G/Fiołas), Co mnie nie zabije to mnie wzmocni (Kaczor, Bezimienni), Błądzisz, to pytaj (Mumin), Nie ma tego złego (Polska wersja). Przysłowia stanowiące semantyczne résumé treści realizują hiperfunkcję wobec tekstu, w którym są osadzone (Szpila, 2009). Inne funkcje (mikro- i makrofunkcje tekstowe, por. tamże) spełniają te paremie, które hiponimicznie integrują się z treścią utworu, stanowiąc jedynie element wypowiedzi. Tak się dzieje w większości przypadków w zebranym materiale hiphopowym. Przykładem takich funkcji niech będzie paremiczny locus z utworu Ry23 Wola Walki. W pierwszej części utworu zawarte zostały dwa przysłowia Umiesz liczyć, licz na siebie oraz Kto pod kim dołki kopie, ten sam w nie wpada. Tekst nawołuje, co sygnalizuje tytuł, do wytrwałości w samorealizacji, w walce o samostanowienie, w obronie własnej integralności i niezależności. Pierwsze przysłowie stanowi radę, namowę do samodzielności, drugie jest opisem ludzi, z którymi przychodzi adresatom mierzyć się jak z przeciwnikami.

58. „Co drugi Polak pierwszemu życzy, niech się wyjebie

Jeśli Ty umiesz liczyć, to licz na siebie

Wtedy wszystko to, co masz zawdzięczasz sobie

Spojrzyj w lustro na swą twarz i powiedz mogę

Wiem, że są hieny, kurwy i zazdrośnicy

Brakuje im weny, werwy, nie błyszczą niczym

Są zawzięci, ten ich męczy, który ma lepiej

Bo na końcu swojej tęczy chcieliby pekiel

Kopią dołki, chcą byś wpadł

Bo nie pasuje im, że patrzysz na ten świat

Który budujesz, brat pierdol to

To zło powróci do nich, Ty to co masz trzymaj

W swojej dłoni, większość goni za tym,

Czego nie może mieć

Łańcuchy i kraty nie zamkną serc

Mogą myśleć tak oni, to już nie ważne

Nie złożymy nigdy broni, to chyba jasne". 
Podobnie jest w utworze Ile jeszcze (LSP), w którym przysłowie Co za dużo, to niezdrowo użyte zostało do scharakteryzowania życia ojca bohatera lirycznego, a w szerszym planie - obrazu własnej rodziny:

\author{
59. „Ojciec zajęty komórkowym telefonem \\ Interesy handlowe robione telefonicznie \\ Transfery, fuzje dawały dochód błyskawicznie \\ Jak mówi przysłowie - co za dużo to niezdrowo \\ Tak się stało, zamienił się na dupę z głową \\ Pochłonął go biznes i błyszczący pieniądz \\ Nie wiedział, że syn jest poza szkołą drugi miesiąc \\ $\mathrm{Z}$ braku czasu przestał troszczyć się o niego \\ Najsmutniejsze to, że nie widział, co w tym złego \\ Nie trudno zgadnąć, co wynikło z tego".
}

Jeśli przyjrzymy się użyciu popularnego w moim materiale przysłowia Prawdziwych przyjaciót poznaje się $w$ biedzie w kontekście dominujących w piosenkach motywów, można mu przypisać metafunkcję, tj. formuły, która używana jest do wyrażenia jednego z najważniejszych elementów kultury hiphopowej, czyli wartości przywiązywanej do braterstwa panującego wśród członków danej grupy hiphopowców. Taki przekaz to przysłowie ma w wielu utworach, np. Klima (Molesta), Bliscy (WSP), Mój ziom (Starszy), Na zawsze (WBU), Wiatr W Oczy... (Jajo\&P.A.G /Fiołas, ale por. Penx, Przysłowia).

W badanym materiale znajdujemy wiele przykładów na to, że polscy raperzy podpisują się pod przekazem przysłów. Tylko czasami rzekoma prawda jest podawana w wątpliwość przy użyciu dystansujących kwalifikatorów typu ponoć (,,a ponoć nadzieja umiera ostatnia to znaczy, że hip-hop oddycha wciąż” Bezczel, Adhd) czy podobno (,Podobno życie zaczyna się po trzydziestce”, DJ Decks, Praż albo giń). W pierwszej kolejności paremie użyte są do konstatacji pewnych zasad, w które raperzy wierzą, którym hołdują i które chcą przekazywać innym i tym samym, nolens volens, je utrwalać (np. w „Jest pewna dewiza, którą znam: Carpe diem, uznają ją ludzie, z którymi gram, o tym wiem, z każdym dniem łapię chwile ulotne jak motyle", Paktofonika, Chwile Ulotne, oraz „Biednemu wiatr w oczy, taka prawda”, Jajo\&P.A.G/Fiołas, Wiatr W Oczy...). Trudno oddzielić zwykłą konstatację od naddanej funkcji pragmatycznej, bo z przyjęcia pewnej prawdy, z uwierzenia w nią wypływać mogą działania pozajęzykowe. Niemniej niektóre piosenki ujmują pewien fragment rzeczywistości, opisując jej mechanizmy właśnie logiką utrwaloną w przysłowiach.

60. „A niektórzy tutaj już pod sobą dołki kopią

Całe szczęście w tym temacie zawsze byłem $\mathrm{z}$ boku

$\mathrm{W}$ rapie jest podobnie, hipokryci lub idioci

Wszystko się tu miesza, dzień z nocą, wóda z koką" (Pezet, Lojalność?).

61. „Chuck Norris już nie gra, obstawia sobowtórów

Nawet z Drużyną A głową nie przebijesz muru” (Tabako, Wychowani w Polsce).

62. „Człowiek jest tylko pionkiem w grze miasto to plansza

Wbrew temu co mówią diabeł tkwi w drobnych niuansach” (Kaczor, Szukając siebie). 
63. „Ty wiesz, że marzenia się spełniają

Bóg pomaga tym, którzy sobie pomagają" (Molesta Ewenement, Ty wiesz, że...).

64. „Widzę wielu, którzy tylko chcą nie mając pojęcia,

że fundamenty piekła są na dobrych chęciach" (WWO, Jeszcze będzie czas).

65. „Do odważnych świat należy, kto w to nie wierzy

Nie ma szans swych umiejętności zwiększyć”" (Bonus RPK, Życie na patencie).

66. „Codziennie nie docenia cię ktoś, czasem to doskwiera.

Człowiek, człowieka wykręci, człowiek wilkiem człowiekowi” (Firma, Niełatwy żywot ulicznego rapera).

Jak wspomniałem wyżej, oddzielenie funkcji illokucyjnej od zwykłej konstatacji jest niezwykle trudne czy wręcz niemożliwe. Powyższe przykłady pozwalają spojrzeć na przysłowia w cytowanych paremicznych loci jak na bezkontekstowe proverbia. Nie oznacza to jednak, że w kontekście utworów ich semantyka nie jest indywidualizowana, nie jest dopasowywana do innych elementów przekazu i nie spełnia funkcji pragmatycznych. I tak raperzy używają przysłów jako rad: „Pamiętaj! Nie czyń drugiemu, co tobie niemiłe” (DonGuralesko, Pamiętaj), „We własnym tempie, co nagle to po diable” (Chada, Hukos, Sitek, Pezet, Pih, DonGuralesko, Jarecki, Niesiemy prawde), ,Trening czyni mistrza, dużo w tym dobrego" (Hemp Gru, Droga), „Do odważnych świat należy, kto w to nie wierzy, nie ma szans swych umiejętności zwiększyć” (Bonus RPK, Życie na patencie), czy przestrogi: „Źle życzysz bliźniemu? Obyś złapał kiłę!” (DonGuralesko, Pamiętaj). Należy dodać, że do tych samych celów mogą zostać wykorzystane stworzone lub użyte przez raperów „nowe przysłowia” („Więc pierdol paranoje i pamiętaj przysłowie, im więcej potu na treningu tym mniej krwi na ringu”, DJ Deszczu Strugi, Jedziesz 2; „Stare przysłowie mówi, że przed libacją dobrze coś zjeść", CeZik \& Klejnoty, Wóda to śmierć).

Zgodę na prawdę przysłowiową odnotowujemy nawet w utworach, które mówią o tym, by nie przejmować się dewizą paremiczną. Tak jest na przykład w polskiej wersji Nie ma tego ztego:

67. „Nie ma tego złego i co z tego, że nie wyszło?

Bo jedno co w głowie mam to zawsze pewna przyszłość. [...]

Nie ma tego złego, nie trać czasu na to!

Nie zamulaj się tym, tym zamulać się nie warto!

Zawsze jest szansa nawet jak Ci coś nie wyszło

Nie patrz na przeszłość, bo ważna jest przyszłość”.

Niekiedy podkreśla się nieuchronność prawdy przysłowiowej:

68. „Śmiejesz się, zgadnij,

Kto się będzie śmiał ostatni,

Śmiejesz się, zgadnij,

Śmiejesz się, zgadnij” (Peja, Co Cię boli).

Albo namawia do wytrwałości w działaniu oraz dążeniu do celu pomimo porażek:

69. „Pozostaw za sobą niepowodzeń pasmo

Lecz nie dolewaj do ognia oliwy 
Wiesz Pan Bóg nierychliwy

Ale sprawiedliwy" (Molesta Ewenement, Dobrze będzie, dzieciak).

Odnajdujemy ponadto utwory, w których intencją rapera jest nie tylko przekazanie konkretnej informacji, osiągnięcie konkretnego celu pragmatycznego, ale także podkreślenie wagi samego przekazu paremicznego: „Pamiętaj! Nie czyń drugiemu, co tobie niemiłe” (DonGuralesko, Pamiętaj), „Wiesz Pan Bóg nierychliwy, ale sprawiedliwy” (Molesta Ewenement, Dobrze będzie, dzieciak). Z drugiej zaś strony twórca dostrzega wartość w wypowiedziach uważanych za przysłowia: „Picie alkoholu to nie moja fobia, ludzie powtarzają moje wersy jak przysłowia" (Kubiszew, Pijackie życie).

Raperzy mają świadomość, że ich słuchacze znają przysłowia, odwołują się więc do utrwalonego paremioleksykonu swoich zwolenników, upewniają się, czy przekaz jest zrozumiały, równocześnie podkreślają tradycyjny charakter użytych formuł: „Chyba znasz to fortuna kołem się toczy, dziś trafisz wszystko na czysto a jutro wszystko umoczysz" (Młody M, Pyskaty, Ero, Chcemy wygrać)

Nieprawdziwość mądrości przysłów, a właściwie ich ograniczoną aplikowalność wykazuje się zaś wtedy, gdy jest zestawiona z rzeczywistością opisywaną przez hiphopowe teksty:

70. „Pani redaktor w telewizji farmazoni:

»Kasa szczęścia nie daje, głupi ten, kto za nią goni!«.

Tak!!? Co ty pierdolisz?

Gówno prawda, Ty nie wiesz, jak to boli!

Zero chaty, jak zarobić duża bańkę uczciwie?” (Karramba, By nie żyć na dnie).

Odrzucenie przysłów sugeruje poszukiwanie własnej drogi w określaniu swego postępowania. Po to, by pozostać sobą, by dobrze żyć, by być mądrym, niepotrzebne są przysłowia: „Chodź tu świecie do nas, razem będziemy się bawić, Chodź tu świecie do nas, bez zbędnych przysłów. Chodź tu człowiek, zobacz tu rządzi mój stan umysłu" (Sobota, Gdybym byt panem świata), „by nadal mówić mądrze nie używamy przysłów” (Hi-Fi Banda, Każdy dzień). Co więcej, ich stosowanie może być postrzegane jako dowód głupoty: „Przyjęli świat jak głupcy bez namysłu, mądrość biorąc z przysłów, prawdę z domysłów" (Eldo, Opakowani w folię). Pojawia się wątek niewiary w mądrość przysłów: „Ty wiesz, że nie wierzę w sny znów, w cel gdy z panoramy znikł już, W sens wypowiadanych przysłów i wytypowanych mistrzów" (Trzeci Wymiar, Nie Wierzę W Nic $J u \dot{\prime} !)$, „Ty chcesz prościej, coś się gmatwa, oszczędź sobie tych starych przysłów, tu nie mam nic już" (Szuwar, Za nim), lub ich zbyteczność w osiąganiu określonych stanów ducha: „Chociaż nie znam setek przysłów, nie narzekam Bo fruzie wolą optymistów” (Łona, Fruźki wola optymistów).

\section{Podsumowanie}

Jak starałem się pokazać na licznych przykładach, polscy autorzy tekstów hiphopowych wyzyskują paremie na wiele sposobów. W pierwszej kolejności paremiczna analiza 
tekstów dowodzi oczywiście, że hiphopowcy sięgają często po przysłowia w konstruowaniu swojej artystycznej wypowiedzi. Jednak ważniejsze od tej kwantytatywnej uwagi są obserwacje dotyczące sposobów wykorzystania treści paremicznych. Nie sposób wobec powyższych spostrzeżeń całkowicie zgodzić się z Shustermanem (1998, s. 295)6 który sugeruje, że raperzy, używając przysłów, przede wszystkim nadają im nowe sensy, modyfikują je, uciekają od ich stereotypowej mądrości czy wręcz je odrzucają. Choć moja analiza nie jest podparta danymi statystycznymi, śmiem twierdzić, że w polskich piosenkach rapowych dominuje umiarkowana zgoda na „mądrość” wyzyskanych proverbiów. Ta być może lokalna cecha paremiczności może stanowić podstawę do szerzej zakrojonych badań nad międzykulturowymi różnicami i podobieństwami w obrębie muzyki hiphopowej.

Wydaje się, że polscy artyści hiphopowi korzystają z całej gamy możliwości, które otwiera przed nimi wykorzystanie przysłów, w pierwszej kolejności modyfikacje i transformacje. Można naturalnie odnaleźć w ich tekstach wiele kontrprzysłowiowych przykładów, aczkolwiek antyprzysłowiowość i odrzucenie paremii nie stanowią dominujących motywów w utworach hiphopowych. Warto zauważyć kreowanie hybrydalnej paremiczności: wykorzystywanie polskich, angielskich, łacińskich paremii, w wersji polskiej i oryginalnej.

Nie należy lekceważyć dodatkowo omówionego w artykule aspektu kreowania rapowej mądrości, która poprzez wyraźnie intertekstualne odniesienia do klasycznych przysłów nabiera cech proverbialności. Ta paremiotwórcza działalność hiphopowców warta jest oddzielnego badania w ramach analiz tworów neoparemicznych we współczesnej komunikacji. Niebagatelnej wagi w końcu jest także językowa kreatywność przeróbek tradycyjnych przysłów, podyktowana w dużej mierze, jak wspomniałem, zasadniczymi cechami muzyki i tekstów hip-hopu, niemniej świadcząca o innowacyjności twórców tego gatunku w odniesieniu do ustabilizowanych jednostek języka.

\section{Bibliografia}

Androutsopoulos, J. (2010). Multilingualism, Ethnicity and Genre in Germany's Migrant Hip Hop. W: M. Terkourafi (ed.), The Languages of Global Hip Hop (s. 19-43). London: Continuum International Publishing Group.

Androutsopoulos, J., Schulz, A. (2003). Spaghetti Funk: Appropriation of Hip-Hop Culture and Rap Music in Europe. Popular Music and Society, 26(4), s. 463-479.

Bennet, A. (1999). Rappin' on the Thyne: White Hip Hop Culture in Northwest England: an Ethnographic Study. The Sociological Review, 47(1), s. 1-24.

Bernasiewicz, M. (2009). Treści kształcące w popkulturze. Chowanna, 2, s. 183-193.

Berns, J., Schlobinski, P. (2003). Constructions of Identity in German Hip-Hop Culture. W: J.K. Androutsopoulos, A. Georgakopoulou (eds.), Discourse Constructions of Youth (s. 197-219). Amsterdam: John Benjamins Publishing Company.

Bradley, A. (2011). Rap Poetry 101. W: Ch. Pence (ed.), The Poetics of American Song Lyrics (s. 35-42). Jackson: University Press of Mississippi.

${ }^{6}$ Stwierdzenie Shustermana oczywiście nie odnosi się do polskiego rapu. 
Chang, J. (2006). Keeping it Real: Interpreting Hip-Hop. College English, 68(5), s. 545-554.

Chorąży, A. (2017). O hiphopowej intertekstualności jako rozmowie. Rap i popkultura: follow-upy i hashtagi. Teksty Drugie, 5, s. 129-146.

Cutler, C. (2007). Hip-Hop Language in Sociolinguistics and Beyond. Language and Linguistic Compass, 1(5), s. 519-538.

Kajak, P. (2006). Utwór hip-hopowy - tekst kultury czy tekst braku kultury. W: J. Mazur, M. Rzeszutko-Iwan (red.), Teksty kultury. Oblicza komunikacji XXI wieku (s. 323-338). Lublin: Wydawnictwo UMCS.

Kozłowska, M. (2012). Ideologia hip-hopowa na przykładach tekstów hip-hopowych. Kultura-Społeczeństwo-Edukacja, 2, s. 119-133.

Majewski, P. (2015). Rap jako muzyka tożsamościowa: od czarnego getta do polskiego pop-nacjonalizmu. Sprawy Narodowościowe, 47, s. 57-79.

Malone, Ch., Martinez, G. Jr. (2010). The Organic Globalizer: The Political Development of Hip-Hop and the Prospects for Global Transformation. New Political Science, 32(2), s. 531-545.

Mieder, W. (2004). Proverbs. A Handbook. Westport: Greenwood.

Miszczyński, M. (2013). „Rapped Resistance and Capitalism”: Contexts, Identities, and Distribution of DIY Rap in Poland. Anthropology of East Europe Review, 31(1), s. 42-54.

Mitchell, T. (1995). Questions of Styles: Notes on Italian Hip Hop. Popular Music, 14, s. 333-348.

Mitchell, T. (2010). Doin' Damage in my Native Lanaguge: The Use of „Resistance Vernaculars” in Hip Hop in France, Italy, and Aotearoa/New Zealand. Popular Music, 24(3), s. 41-54.

Moch, W. (2002). Słownictwo swoiste polskiej subkultury hiphopowej. Język Polski, LXXXII(3), s. 188-197.

Moch, W. (2008). Hip Hop - Kultura miasta. Leksyka subkultury hiphopowej w Polsce. Bydgoszcz: Wydawnictwo Uczelniane Wyższej Szkoły Gospodarki.

O'Hanlon, R. (2006). Australian Hip Hop: A Sociolinguistic Investigation. Australian Journal of Linguistics, 26(2), s. 193-209.

Pasternak-Mazur, R. (2009). The Black Muse: Polish Hip-Hop as the Voice of „New Others” in the Post-Socialist Transition. Music and Politics, 3(1). Pobrane z https://quod.lib.umich.edu/m/mp/9460447.0003.103/-black-muse-polish-hip-hop-as-the-voice-of-new-others?rgn=main;view=fulltext (5.05.2019).

Pate, A. (2010). In the Hart of the Beat. The Poetry of Rap (African American Cultural Theory and Heritage). Lanham: Scarecrow Press.

Pennycook, A. (2003). Global Englishes, Rip Slyme, and Performativity. Journal of Sociolinguistics, 7(4), s. 513-533.

Pennycook, A. (2007). Language, Localization, and the Real: Hip-Hop and the Global Spread of Authenticity. Journal of Language, Identity, and Education, 6(2), s. 101-115.

Picz, R. (2009). Hip-hop - muzyka amatorów czy wysoce profesjonalna forma komunikacji? W: A. Maj (red.), Amatorzy kontra profesjonaliści? Nowe formy komunikacji w kulturze wspótczesnej (s. 80-89). Katowice: Wydawnictwo Naukowe ExMachina.

Sawicki, K. (2003). Młodzieżowa kultura hip-hop jako tekst wielokulturowy. Ars inter Culturas, 2, s. 95-104.

Shusterman, R. (1998). Estetyka pragmatyczna. Żywe piękno i refleksja nad sztuka, przeł. A. Chmielewski. Wrocław: Wydawnictwo Uniwersytetu Wrocławskiego.

Szpila, G. (2003). Krótko o przystowiu. Kraków: Collegium Columbinum.

Szpila, G. (2005). W poszukiwaniu prototypowych kontekstów paremicznych. W: A.M. Lewicki (red.), Problemy frazeologii europejskiej, VII, s. 27-37.

Szpila, G. (2009). Physical Anchoring and Referential Scope of Idioms and Proverbs in Literature. W: T. Fedulenkova (ed.), Cross-linguistic and Cross-cultural Approaches to Phraseology (s. 171-181). Arkhangelsk/ Aarhus: Pomorsky State University Press.

Szpila, G. (2014a). Znajomość przysłów wśród polskich studentów - minimum paremiologiczne. Literatura Ludowa, 4-5, s. 87-101.

Szpila, G. (2014b). Kompetencja paremiczna młodzieży akademickiej w badaniu ankietowym. Literatura Ludowa, 6, s. 45-58.

Szulc, M. (2014). Postawy hip-hopowców wobec własnej podkultury. W jaki sposób widzą siebie hip-hopowcy. Kultura i Edukacja, 3(103), s. 313-339. 
Warren, A., Evitt, R. (2010). Indigenous Hip-hop: Overcoming Marginality, Encountering Constraints. Australian Geographer, 41(1), s. 141-158.

Williams, J.A. (2015). Introduction. W: J.A. Williams, The Cambridge Companion to Hip-Hop (s. 1-8). Cambridge: Cambridge University Press.

Więsak, M. (2006). Piosenka hiphopowa jako sposób na odzwierciedlenie rzeczywistości. W: J. Mazur, M. Rzeszutko-Iwan (red.), Teksty kultury. Oblicza komunikacji XXI wieku (s. 313-322). Lublin: Wydawnictwo UMCS.

Wójciuk, A. (2017). Ekspresywność języka subkultury hip-hopowej. Zeszyty Naukowe Towarzystwa Doktorantów UJ, 3(18), s. 67-79.

Wójtowicz, S. (2014). O kierunkach w polskich badaniach literaturoznawczych nad hip-hopem. W: M. Miszczyński (red.), Hip-hop w Polsce: od blokowisk do kultury popularnej (s. 183-198). Warszawa: Wydawnictwa Uniwersytetu Warszawskiego.

Żmuda, M. (2014). Pasaże tekstowe w polskim hip-hopie. Analiza opisów przestrzeni miejskiej w wybranych tekstach rapowych. Konteksty Kultury, 11(2), s. 143-156.

\section{STRESZCZENIE}

Słowa kluczowe: hip-hop, rap, teksty piosenek, przysłowia, język polski.

W artykule przedstawiono analizę przysłów w wybranych tekstach polskiego hip-hopu. Artykuł omawia miejsce paremii w tekstach rapu, prezentuje przekształcenia formalne (gramatyczno-leksykalne) i semantyczne proverbiów oraz bada znaczenia wykorzystywanych przysłów w kreowaniu ideologicznego obrazu polskiego hip-hopu.

\section{SUMMARY}

\section{Proverbs in Polish flowklore}

Keywords: hip-hop, rap, lyrics, proverbs, Polish.

The article discusses the use of proverbs in Polish hip-hop lyrics. The paper talks about the presence of paremias in Polish rap songs, analyzes their formal transformations (enumerating syntactic and lexical changes in the shape of proverbs), as well as examines the exploitation of proverbial semantics with a view of presenting individual and more general values of the Polish hip-hop community. 